Miodrag Vukčević

Faculty of Philology

University of Belgrade
UDC 371.3::821.112.2(497.11)

DOI https://doi.org/10.18485/fid.2017.7.ch17

\title{
GERMAN MINORITY LITERATURE IN SERBIAN UNIVERSITY CURRICULA
}

Настава немачке књижевности на универзитетима у Србији се третира у контексту традиционалне филологије. Осим тога, треба напоменути да дефиниција овог предмета у оквиру студија германистике јесте наставни план и програм за студије немачког језика и књижевности у иностранству. Међутим, да ли студије немачке књижевности у смислу књижевности писане на мањинском језику покривају исту специфичну област? Књижевност настала на језику одвојена од области из које потиче, сигурно има више нити развоја, нарочито две, једну одређену већинским језиком и другу одређену сопственим правом, коју је пренео језик порекла. Осим тога, историјски гледано, миграциони покрети заједнице Дунавских Шваба парадигматски показују коефицијент детериторијализације која, пре свега, утиче на језик. На основу овога, Делез и Гатари дефинисали су мањинску књижевност путем мале или мање књижевности мањине која користи језик који другде говори велика заједница. Међутим, ширење немачког језика расипањем преко различитих језичких заједница у Источној Европи и изолација сваке од њих, чини да немачка мањинска књижевност изгледа уједињено. С друге стране, ипак, чини се да је увек у директној размени са већинском културом која је окружује. У случају српско-немачких културних контаката, изнете су студије урбане и локалне историје Баната локалног немачког историчара и археолога, Феликса Милекерса (рођен 1858. године), што је значајно за српску историју, као и за регион где је истраживање спроведено, а и за немачку дефиницију области порекла. Очигледно, подела у сферама интересовања покреће питање приступа у циљу дефинисања предмета. Да ли говоримо о мањинској књижевности посматраној из перспективе српског језика и књижевности и, ако као таква постоји, да ли то укључује поезију коју су написали чланови немачке мањинске заједнице на српском језику? У другим језицима, има таквих случајева. Да ли, пак, говоримо о мањинској књижевности посматраној из перспективе студија германистике?

Немачки аутори који долазе из јужне Мађарске и касније из Краљевине Срба, Хрвата и Словенаца, никада се не би могли приближити тенденцијама да су признати у књижевности која је настала на подручју немачког језика. Док књижевност Дунавских Шваба из јужне Мађарске и Краљевине Срба, Хрвата и Словенаца или Југославије није чак ни близу књижевности награђиване, у међувремену, Нобеловом наградом, њихова књижевност значајно је допринела самооткривању културе која карактерише Дунавске Швабе. Иако није био потомак Немаца који су живели у области 
углавном насељеној Србима, Адам Милер-Гутенбрунов роман "Glocken der Heimat“" је награђен роман који сведочи о судбини Немаца који су живели у месту Книћанин, док Карл фон Молеров ”Die Werschetzer Tat“" описује успех Дунавских Шваба у гајењу земље и ширењу цивилизације.

Кључне речи: идентитетске конструкције, коефицијент детериторијализације, култура сећања, културна пракса, мањинска књижевност, међукултурна комуникација, пијачна насеља, Подунавске швабе, приступ одоздо на горе, транскултурно поређење

\section{Access to German studies in Germany and abroad}

Generally speaking, it is well known that teaching a foreign philology has various aspects that are quite different compared to a philology taught as native. This has a bearing on the topic discussed in this paper, and should be mentioned as the perspective from in which the respective language, literature and culture are received. As for German studies in general, first it should be stressed that this field of humanities is divided into three subgroups. More specifically, research in German studies carried out in Austria, Germany or Switzerland sets an agenda which always depends on the historical framework that is set by the national institution that the research is supported by. Nevertheless, regardless of these diachronic differences, actually categorizing a philology means making a distinction between its linguistic dimension and the literature that articulates its cultural values. An analysis of the general historical context, however, in some cases widens the area of philology to the third discipline of medieval studies. Furthermore, modern approaches like educational strategies, expressed in declarations or those determined by the latest theories have their special impact as well. All of these features apply to German studies pursued as a native philology.

Another aspect is teaching German as a foreign language. In Germany, university curricula show that German language studies as a foreign language (Deutsch als Fremdsprachenphilologie) serve to educate students planning to find employment abroad as Germanists. German studies abroad, the so-called Auslandsgermanistik, practiced by native speakers who teach German outside Germany, serve to popularize cultural values 
and the German language adjusted to the requirements of the source community. And, of course, the presence of the German language outside the German speaking area has to be considered in the context of cultural and literary history mainly as part of a third scientific area, namely as a minority language and literature.

However, none of these characteristics is concordant with teaching German and literature as a foreign language abroad, by someone who does not speak German as a native speaker. Neither can the subject be taken to be a source culture nor is the target community able to retrace the foreign values in their entirety. Studying German as a minority language and literature in a country where German language and literature were historically part of a multicultural society differs from the position of origin as well, as they have never been part of the society. The previous mentioned case offers the possibility for treating them either as a constitutive party or as an alien influence, or more precisely, a foreign impact. This, obviously, depends on historical circumstances, while in the latter the influence of history is relative.

Speaking from experiences gathered in the Serbian-German relationship, it is obvious that history has left traces. In this context, Zeitler's definition of geographical aspects determined by space (2001: 130) has gained a twofold importance. On the one hand, it is possible to establish similarities in the identity construction of German and Serbian citizens. In the case of Germany, this is an identity which recognizes itself in a central position between the cultural spheres of East and West, in comparison to which Mitrović describes the culture of Serbia as emerging on on the route between Southeast and East, and Western Europe (1996: 7). On the other hand, exactly these geographical aspects, determined by space, have led historically to confrontations between these two nations. Furthermore, the German identity in the Balkans is also connected to a minority identity. During migration of German settlers from the beginning of the $18^{\text {th }}$ century, the cultural forms they brought to the middle and upper Danube area provided the basis for creating an awareness, which was specific for people of German descent. The perception of social life from this changed perspective, caused by specific historical circumstances had a special influence on determining the German identity in the Danube area (Hilkener, 1932: 2-7).

Therefore, from the Serbian point of view, teaching German literature at home universities has to take into account two different German 
identities. To that extent the positions to be taken with respect to both identities, must also be different. First, the history of German literature is received as a reflection of the history of a nation, the values of which are discussed within the framework of the disciplines of philology and humanities alike. However, the minority literature approach has been shaped by the historical ramifications and results of World War II. Moreover, historically speaking, the contact between German and Serbian culture is marked by a language contact that manifested the main subject of interest between these two nations.

\section{German studies in Serbia}

Looking at the university curricula in the seven state Universities in Serbia and at the curricula of the private universities and faculties, we see that the German language is not taught at all of them. When German language is included in the curricula, the basic approach is evidently to teach it as a foreign language. However, at some of the observed faculties, the German language is taught for the purpose of educating translators. A number of new private universities have announced that they will open, but only four universities, among them three state universities, namely those in Belgrade, Kragujevac and Novi Sad also have German literature in their curricula. Whether the private one in Novi Pazar will include the German language in its curricula remains to be seen. On the one hand, it seems that an insufficient number of students is interested in studying German in the south-west area of Serbia. While, on the other hand, in the Northern Province a stable number of students graduates in this field.

Again, we cannot find German as a minority literature in any of these curricula. The approach to German literary studies is incorporated into the study of German language, and starts for the most with teaching the beginning of literacy for the Germanic tribes of Central Europe. Regardless of the very beginning of literary studies and the question of whether a department starts with an introduction into German literature, the approach arranged by academic years or semesters starts exclusively according to the chronological timetable. Whether the previous knowledge of the students is based on classical German works or modern literature might raise their 
expectations of attending lectures on contemporary German literature, and proceeding this way could perhaps be a much easier practice, and the path of least resistance.

Studying foreign language philology in Serbia usually means studying language, literature and culture. According to this framework, the Faculty of Philology at the University of Belgrade divided its curricula into the possibility of enrolling either a subject of the Serbian language, literature and in this way, a comparative field of study, or studies of Language, Literature and Culture offering 20 different languages. There are of course subjects offered, which are of great importance for philological studies like Librarianship, Computer Science or General Linguistics and General and Comparative Literature. But the aforementioned approach is certainly determined by the tradition of teaching foreign language philology in Serbia. In line with the tradition, the other two universities that also teach German literature follow the same concept. When defining foreign language studies in relation to studies of one's own philology, the idea starts conceptually with cultural practices. So the basis for studying a foreign literature at Serbian universities, including German literature, is always a contrastive approach that explores cultural practices that resulted in an artificial form of communication. The distinction, which is made to define the subject of literature, follows the continuity of cultural differences based on the cultural life expression.

The question of studying German literature at universities in Serbia can be divided into several segments. First, it is a question of a) the curricula, and then b) language, literature and culture as philological disciplines. Moreover, studies starting from a historical aspect as a possible third approach for research have to differentiate between the history of German people in the context of European history in general, on the one hand, and the history of Balkans or South East Europe related to the German people specifically, on the other. In multiethnic and multicultural surroundings, as in modern Serbia's northern province, the approach should take into account questions of the tradition of the different ethnic communities. Speaking of research on the Serbian language area in this third aspect naturally, the Serbian culture is of primary interest. But with regard to the different traditions according to the mode of established social re- 
lations and ethical values being in the centre of attention, the question whether customary rights abide by Germanic legal customs or the communication with the forces of life, seem to be obviously widely diversified through an approach to studying literature written in German as a minority language.

\section{Cultural and historical aspects of teaching German literature in Serbian universities}

Even when teaching earlier German literature, starting for instance with the Songs of Heroes, certain differences can be noticed in understanding the function of poems based on legends and the role of their heroes. An explanation of differences between German and Serbian interpretation approaches could be found in using the dynamic identity concept of Ricœur and his definition of the narrative identity that results from the relation between matching and differentiating (Wodak, 1998: 490). In German literary studies the Georgslied (896), Song of St. George, for example, is commonly known to have originated conceptually from singing a hymn in a community while exercising a liturgy (Frenzel, 1999: 12). The oldest German poem singing about a legend was written on the occasion of founding the early medieval Abbey Reichenau and praises St. George as the martyr of indestructible life who repeatedly returns from death. According to the Legenda aurea by Jacobus de Voragine, later on, from end of the $11^{\text {th }}$ to the $13^{\text {th }}$ century the evolution of the poem in terms of a cult spreading from Reichenau to the Abbey St. George in the Black Forest appears in connection with the Crusades (Hackemann, 2008). In the role of the miles christianus the knight George kills the dragon, death personified in the fire spitting symbol of hell. This picture determines the idea of St. George in Serbian culture mostly because of the icon and its important function in the Orthodox Church.

The values expressed in the courtly ethos along with the ideas of virtue, whether based on Ehrismann's ideas about a virtue system which was derived from ancient moral philosophies (1970) or Curtius' melting pot thesis of Germanic, church, ancient and Spanish-Arab elements (1948) seem not to be relevant in Serbian cultural history at all. In the centuries to come 
during the Middle Ages the unequal spiritual development in Europe resulted in the development of specific cultural forms. Due to historical events, the timing made it possible for some of the people more and for some less to articulate their own being. The development of German culture was later on compared to the neighboring cultures mainly because of the wars fought in every century, also repeatedly, beginning from the late Middle Ages till Early Modern Times. It is also well known how much time was left for Southeast Europe to join and follow the spiritual contents that spread in the regions less affected by pressures of foreign culture, while Central and Western Europe were occupied with themselves and with dividing the world. This could be one of the reasons why in the process of ethical evaluation in the Balkans in the Middle Ages, religious contents received more attention than in the case of values derived from philosophy.

Another approach to teaching German literature is certainly studying its context as a minority literature. In Serbia, as in other countries where German people were part of the society for a certain period of time, understanding German literature as a minority literature positively can neither include the entire experience the German people had in each and every European country they lived before, nor retrace the historical consequences, in the same manner. The experience a specific nation had in contact with the German people being historically together under the same administrative umbrella is a different one compared to the experience of the German people as well as to each one pertaining to the other nation that made its own experience. A specific procedure of the German people in their social functioning matches surely regardless of the cultural surrounding they are faced with by another nation. In addition to the context of the historical migration of the German people and the cultural development that stems therein, their cultural practices of organizing the community ought to be considered, too.

\section{German culture, customary law and social development}

The current approach at the Serbian universities starts with searching first the artificial value and further on the reflective dimension of literature, but does not take into account the history of the legal tradition, which is based on the customary law. Within that bargain, this has served tradi- 
tionally for making decisions in the process of socializing the community. Historically speaking, the institutionalization of decision-making in the community also has its tradition. Known since ancient times as a 'thing', the people 's assembly, whose function was to make legal decisions, served to ensure order in the community. Hence, a legal order in the community, in ancient Greece arisen from the needs that resulted from growing urbanization, was also part of the traditions of the German people from the time they settled in Central Europe.

By organizing itself into the communities of German tribes, it left traces, which testify to the values significant for the community and their functioning. The need for regulating their community gave rise to law books from the end of the $12^{\text {th }}$ century. Even if the German tribes were not the only ones to have the earliest law books, understanding the history of how different law books came into being could help to improve knowledge about how social relationships are composed with respect to justice and honor. Organizing the legal order in the town, the oldest German law book, the Mühlhäuser Reichsrechtsbuch written in the early $13^{\text {th }}$ century in the Thuringian Mühlhausen had its influence on constitutional history as well as Matrimonial and Family Law (Adenauer, 1962). In the period of the transition from the $12^{\text {th }}$ to the $13^{\text {th }}$ century, with the attempt made by Eike von Repgow to document and systemize the law of the Saxons the so called Mirror of the Saxons (Sachsenspiegel) emerged. This was the basis for the Mirror of the Germans (Deutschenspiegel, around 1275) which collected regulatives from the Roman law, Canon law and Bavarian customary rights. About that time, a similar law book written by a Franciscan friar appeared in Augsburg for off-Saxon Germany. The Mirror of the Swabians (Schwabenspiegel) reaches back to the Bible, Roman and Canon law and tells about law in the German Reich.

The first evidence of town privileges were definitely the result of the customary law as was illustrated by the example of Bavarian customary law. The town privileges replaced originally the imperial or sovereign prerogatives (Stadtregal) to raise a village or suburban settlement to a city. Although they did not represent any unified "city law", the town privileges consisted of several privileges (settlement rights, customs) and individual rights of which the market law is the oldest one. Town privileges are testified to in 1235 in Burghausen, 1294 in Munich with the so called Rudol- 
finum, 1274 in Dingolfing and 1312 in Ingolstad (Liebhart, 1980). In the two aforementioned and the town privileges of Munich, it is possible to recognize the lexical root "thing". In connection with structuring principalities, it should be pointed out that these occurred particularly in Old Bavaria to the founding of a greater number of markets and some towns. The result was an urban landscape structured in three levels consisting of residential cities, small towns together with district courts and the market town (Liebhart, 2006). Compared to modern German urban history, these model types were developed for describing the formation and establishment of towns counts till 1150 with Old Cities belonging to Roman history (so called Mutterstädte like Cologne, Bonn, Koblenz, Trier), from 11501250 with founded towns, from 1250-1300 with (small) towns and from 1300 with Minderstädte or Minor Towns.

Though this type model does not take into account the market towns (Marktflecken) from southeast Germany, i.e. Bavaria and Austria. This type of settlement is regulated as a locality which does not comprise arable farming, but rather professions and trade. Considered in its historical context, this form of settlement was an instrument of territorial policy. According to their growth, settlements or villages first received market privileges and then became Minor Towns with limited civic rights. The oldest of these is the Borough of Soest (Hartung, 1995). This was the basis for several other boroughs and for the spreading this tradition to other areas populated by German people. Because of its significance for the jurisprudence in the Middle Ages but moreover for the Customs, which evolved from it, the Borough of Soest still has an influence on today's understanding of the historical link with some traditions. While the term "Ostsiedlung", which the German eastward expansion is called, stands in line with the idea of the aforementioned matters, the context of cultural history regarding Europe is connected unilaterally.

Now, in order to teach German Literature as a Minority Literature in Serbian university curricula there are many indications why studying this subject should be based on historical experience. Anyhow, it is not possible to obviate these because they resulted from historical events. Basically, the first commonalities of cultural development are to be determined. The chronicles of the crusades testify to the meeting of Fredric Barbarossa and 
Stefan Nemanja in Nish while the former was passing through Ras, the Serbian state in the Middle Ages and preparation for this meeting earlier in Kruševac and Nuremberg (Petrović, 1998: 18-21). On the other hand, there are of course a lot of differences in the cultural development as a consequence of the course of history. This is most probably the influence of the territorial policy of the European powers and their allocation.

\section{German culture in a literature of remembrance in Serbian-speaking area today}

The approach to introducing German literature into the Serbian university curricula as a minority literature follows first of all the historical experience which is a result of the historical events that happened on the territory where the Serbian people have lived since their migrations to the so-called Western Balkans. Of course, in addition to the settlement and cultivation under The Habsburgs from the $18^{\text {th }}$ century socio-historical moments can also be recognized. These form much more material for studying joint structures in society. The "bottom-up" approach starts with investigating the history of certain villages and towns where German citizens were part of the society until World War II. In Indjija for instance today's town center got its still partly preserved image a decade after the appointment of Joseph Folks in 1834 as Judge (Wilhelm, 1961). The town hall, after Syrmian custom with a front shelter (Serbian "trem") and walled circular columns, was placed in the center. Today, this example should serve to illustrate current trends in identity change. "Iudex oppiandus Indiae", "judge of the borough of Indjija" is the title by which the 1825 immigrant Senator Joseph Folk was named on June 8, 1834 to be the first German judge of the town (Oberkersch, 1978: 89). Even in 1822 mentioned as 'Oppidium' in the Habsburg archives as a market town with its own market law, unlike the villages, Indjija had the right to organize fairs (Timotijević, 2006: 105) and was a burgeoning small town. The tradition of annual fairs nowadays has been transferred to Serbian customs, according to the domestic rites. In this regard the Serbian identity is known for its hospitality more lasting than several decades or even centuries. On the other hand, with regard to the historical aspect of urban formation, the so called marketplace or small market town can be retraced mainly in the 
northern province of Vojvodina, which reminds us of the tradition of the settlement history known in the southern parts of the German empire.

Despite different approaches, comparative studies always search for the ideas hidden in the artificial form of a language. By comparing poetry written in different languages, similar forms are stressed and taken as manifestations of a common movement. On the other hand, historical development has caused cultural differences with respect to historical phenomena and phenomena in the history of civilization. Teaching foreign language literature and poetry educates based on foreign cultural values. Caught between different values, cross-cultural communication proceeds via stereotyped notions led by historical ideas that are bogged down in the same culture from which these stereotype notions originated. On the one hand the teaching approach at the university on the topic of German eastward expansion certainly take account of cultural aspects belonging to the German nature, but research in this direction does not include the cultural impact.

Literature used to encourage recollection shows the possibilities of how to achieve greater success with the 'bottom-up' approach. This approach starts from the regions characterized by village culture where memories lean on autobiographical storytelling, memoires, or literature, all of which collect individual destinies, while the history is revaluated in an urban environment. In the meantime there are some book titles which refer to the German minority in the Vojvodina and which are dealing with their destiny. Illustrations and interpretations of both indirect and direct influence of literary and scenic and visual testimonies or monuments of German identity respectively on German identity have failed to materialize so far. But, modern theories, which summon up history again, offer also interpretations that deal mainly with the disastrous consequences of war. Nevertheless, a transcultural comparison through history can be established by merging these two tendencies. According to the words of Lehmann (1995: 27) this will portray the relationship between two nations by means of folklore, or yet, by describing the stereotyped images of one another, thus promoting a better mutual understanding. Exposed to subjective interpretation, the meaning retained in the images of each other indicates a large number of tie points articulated in the cultural contact.

Recalling again the custom of organizing fairs, one should mention that it is a habit nowadays too. The custom of celebrating the foundation 
day of a settlement linked with religious holidays in honor of a patron might be a connection to town parties like the Soester Bürgerschützenfest which takes place on every first Saturday after St. Johns Eve. Traditionally on the following Tuesday, according to the custom of second day's decision-making, a "Seesaw in the Big Lake" is being organized at this fair. This shall remind us of the way of punishing garden thieves and poachers, which was a custom since the $14^{\text {th }}$ and was used till $18^{\text {th }}$ century (Schild, 1997: 196). The city fathers of Soest linked together the custom of organizing fairs and the tradition of ruling justice. They hired a painter to create the Book of Useless Bunglers in 1315 (Hartung, 1995: 27). On its pages, each and everyone should be shown a powerful reminder of tough penalties he is threatened by if he does not adhere to law and order.

A source for collecting information concerning the cultural history of a nation certainly belongs to the so-called books of towns, Stadtbücher, like it is the Alte Schrae, certainly the main source for getting to know the history of the town privileges of Soest and the German town privileges in general. A comparison for the Western Balkans respectively the development of an understanding of the settlements, which connects the Western Balkans with Central Europe in terms of contents determined by cultural history and forms derived from civilization history, is rather bound to the southern German-speaking areas. This can be recognized from the settlement patterns, the town hall as a symbol of bourgeois self-government and autonomy that was built in the center or at the edge of the courts. The aforementioned case law is undoubtedly linked also with the jurisdiction of a county judge who exercised his function as a judge in a town or a market.

From the perspective of Serbian cultural achievements, the German share of European cultural expression can be described also as an integral part of Serbian identity. In this sense, the culture of remembrance in Serbia, which is dedicated to the German heritage and which should be included in the European concept, depends on the literature of remembrance that does not rely only on historical events or the localized or located memory, but it is also the result of a literary discourse that manifests German contribution to the acculturation of Serbia (Konstantinović, 1991: 17), then by turning it to the Central European culture. However, in this case the Serbian identity according to Ricoeur's categories is defined as a narrative one (1996). 
Indeed, the development of a culture of remembrance en detail requires on the one hand something like locating certain places of memory. Further on taking into account the so-called "coefficient of deterritorialization" (Deleuze/ Guattari, 1976: 24) which says that the German minority in the province Vojvodina was connected to the German-speaking region in some places more and elsewhere less and that the conditions for the care of one's own culture outside of the German speaking area varied the other hand from place to place (Mirambel, 1966), the exposures for an identity management are primarily addressed to the local administrative structures. On the example of Kosovo and the recently appeared internal scattering it becomes obvious how such ideas in the application evolve to a new historical dimension.

\section{Serbian-German Cultural contact}

In context of the writing culture that is decisive for us, and that we want to pursue, is of particular importance that a writing culture with its development articulated in periods shows social gradations. In Bavarian regions Freising, Regensburg and Salzburg are to be mentioned and earlier in the High Middle Ages Passau and Vienna are to be added. However, Nuremberg has certainly not as such an importance of being a writing location, as it will have in the late Middle Ages. A very interesting aspect in the Germanic-Slavic cultural contact surely is the role of cultural centers in the Middle Ages. Nuremberg in the South was one such centre of the spiritual and secular festivals of the Middle Ages. Also a centre for secular festivals, but in the North, was Luebeck. Here the Brotherhood, a circle of merchants coming from Westphalia united in a society since the $14^{\text {th }}$ century, raised the moralistic finger each year.

Luebeck, a settlement founded by Slavic tribes in the $8^{\text {th }}$ century (Nikolajević 2003), was gifted with the Soester Town Privileges in 1160. The early legal tradition in this town helped the immigrants from Westphalia to ascend economically by trade. As a sign of the desire for social ascent, the roots of the settlement described in the Slawenchronik were revised and pursued on Latin as well as the Middle High German narrative poem Gregorius was translated on Latin too. Their approach not to neglect the own history interconnected with a desire to lean on a Latin tradition has elevated the burgeoning culture. Further on the progress in civilization 
(Theiß/ Wolf, 284-288) supported by the different traditions, legal, trading and linguistic, was a solid foundation for trendsetting perspectives.

By transferring these findings to the region of the Western Balkans, it is possible to recognize relations like the described. Whether it is a culture evolved in architecture or urbanizing, the language reflects historically the cultural development. The tradition of farmsteads, which consist of residential and farm yard, with extensive orchards and vegetable gardens, originate from Vojvodina and spread out from here all over the country. There are these striking three-sided farmyards, with the hooks houses on the eaves side, which are followed by the extended buildings backwards, and which is opposed to the street front. It is also possible to find here the so-called 'Tschardaken', how they were called by the Germans or 'kotobanje', as it is called on Serbian. These are known as corn reservoirs calling to mind the continuously lasting agricultural orientation. Doubtless, synonyms are elaborating a vocabulary of a language Stereotypes support the possibilities of getting a better insight in cultural measures even in the context of time-honoured, reactive modern language tendencies, or unintelligible for students learning a foreign language. This is decisive in particular for the source culture that determines the line of analysis. In this respect, stereotypes help in reflecting one's own cultural values when comparing them to foreign cultural habits.

In order to get to the values that were crucial in the relationship between German and Serbian settlers, their everyday life must become the focus of attention. The identity of the German minority in the Serbian speaking area could be investigated from the perspective guided by a bottom-up approach. This would mean taking a region that is rural in character, where communal recollection relies on autobiographical narrative, memoir or literature which collects individual life histories. Research at the local level, which is understood as a microstructure, the view "from below", helps to recognize the impact that manages the identity of each individual citizen.

\section{German cultural heritage in Serbian remembrance literature}

There is, of course, the problem of expressing the own identity, defined throughout history. Nevertheless, since the access to cultural recol- 
lection is realized primarily in cultural texts, such as historical sites, once potential carriers of the epithet "the place to recall", describing the former architecture, preserved in literature with the aim to gain recall (Panković, 2000). Using the bottom-up perspective a number of titles dealing with the German minority in Vojvodina and their fate will be mentioned with presentations and interpretations of the direct and indirect impacts of literary and artistic testimonies and monuments to the German identity. But modern theories, questioning history, offer interpretations which focus primarily on the fatal consequences of war. Establishing a transcultural comparison throughout history is definitely possible by merging these two tendencies. This would portray the relationship between the two nations with the help of folklore or description of the stereotyped presentation of one and another, promoting better mutual understanding at the same time. According to Dröge (1995: 8) teaching of literature in foreign languages, educating and upbringing should be based on cultural values enshrined in local cultural tradition. Communication between the two different systems of values is carried out through stereotypes formed throughout history. Exposed to subjective interpretation, meaning is retained in images of another point at a large number of contact points, that articulate themselves in cultural contact.

Goethe's Faust offers us an example of how literature realizes and reflects cultural contact. Enthralled by the idea of colonizing the dried swamp areas, Goethe in the fifth act of the second part lets Faust himself speak in the atrium of the palace about settling areas that were freed of water as the deepest meaning of life and the highest ideal of human existence. Mainly in the period of the $19^{\text {th }}$ century, Serbian intellectuals travelling to the German speaking area and studying there contributed to Serbian culture by writing poetry about their impressions and experiences. They brought the ideas collected in Germany to Serbia and gave their people the chance to join the process and progress of modern Europe.

On the other hand, German authors coming from southern Hungary and later on from the Kingdom of the Serbs, Croats and Slovenians could never get close to tendencies that were recognized in literature originating from the German language area. While the literature of the Danube Swabians from southern Hungary and the Kingdom of the Serbs, Croats 
and Slovenians or of Yugoslavia is not even on the verge of a literature awarded in the meantime with the Nobel Prize, like Herta Müller, their literature contributed significantly to the self-discovery of a culture that characterizes the Danube Swabians. Although he spent the greater part of his literary life in Vienna, Adam Müller-Guttenbrunn did something that was not an inconsiderable part of the self-image of the Germans living in Banat. Like his novel Der große Schwabenzug (1913) his rewarded novel Glocken der Heimat (1911) presents the German population living in South-East Europe as a separate ethnic community with common sociohistorical roots. But in the context of a multicultural society as it existed in the southern and eastern parts of the Habsburg monarchy, where tendencies to unify on the basis of ethnic origin in a historical context, are more common than ever today, this is easy to misinterpret. The reward Gutenbrunn received for identifying the local characteristics of the German people living in Knićanin/ Rudolfsgnad, is not overshadowed only by the position he took against other ethnic communities, especially Jews, but also by the mass grave, which was filled with German people buried after World War II ended. Even though he was not a descendant of the Germans living in the area mostly populated by Serbs, he found a region that testifies not just to the destiny of the Germans, but also about the scene of action at the confluence of the Tisza river and the Danube. Moreover, he put an accent symbolically on the success of the Danube Swabians in cultivating land and spreading their civilization, as described previously by Karl von Möller in his Die Werschetzer Tat.

On the transition from the $19^{\text {th }}$ century to the $20^{\text {th }}$ it is possible to retrace a mixed cultural live in several social segments. Cultural activities took place in a so-called reading society, whose aims were fostering the mother tongue using books in German. The list of books that were read contains authors' names like it is Ludwig Anzengruber and Ludwig Ganghofer, Adam Müller-Guttenbrunn and Karl von Möller. Being up to date at that time, however, the list does not include many names of prominent poets whose titles are inevitably part of each literary history today. Anyhow, the listed ones are representing a specific culture that articulated its values different from the German culture that was present in Germany, the Austrian part of the Habsburg monarchy or Switzerland. 
Getting to know the culture of the German population living in cultural contact with Serbs from the $18^{\text {th }}$ century on, naturally, has to take into account the surrounding of the culture as well as the conditions for its existence. In any case, the approach to exploring has to start from certain areas because the culture in a multicultural space needs to be limited. This of course is part of the problem per se. In order to single out certain cultural forms, they have to be located. In Syrmia County as well as in all other areas a minority identity arises in direct contact with the majority population and / or other ethnic minorities in the local environment. A "bottom-up" - perspective starts from areas that are marked by rural character, where memory leans on autobiographical narratives, memoirs or literature describing destiny, fate literature, while the history is reprocessed in an urban environment. According to the subdivision by Ariès, Duby and Veyne into literature on beseemed behaviour, autobiographical literature, the penchant for solitude, friendship, taste and family home, these authors raise the question about the development of a modern understanding of privacy (Timotijević, 2006: 8). In this respect, the meetings of the reading association are in particular important in the sense of cultural history. One very significant example are the sessions in which the agricultural labourer Jakob Köhl led the presidency, and which took place in one of the villages of the Indjian municipality, in nearby Krčedin. An interesting item is undoubtedly that the meetings were held first in the pub of Philipp Hegel, one of the initiators.

Despite its poor literary quality, the information accessible in the literature dedicated to memories, can offer a point of departure for understanding the emergence of a culture from cultural contact. This refers mainly to the formation of institutions such as schools and churches which could be hard to separate while contemplating these two communities. The urban basics set in earlier centuries, road construction and naming streets (Marković, 1997) remind us of a common history. The practice in organizing the community (Lukić, 2002: 22) is linked with many factors in social life of earlier periods too. This goes also for the manner in which cultural contents in a multicultural society were incorporated into the educational system.

Today, however, the buildings that had emerged at that time are setting free the space for a new, modern residential and commercial architec- 
ture. Besides the experience, which was gained in the Former Yugoslavia with respect to the institutional hedged coexistence of a multicultural society, the multicultural image of townscapes vanishes. According to the fact that signs of a culture of remembrance primarily realize themselves in texts to cultural life, historic sites, once potential carriers of the attribute "locations of memory" describing earlier architecture therefore are preserved in literature dedicated to remembrance (Panković, 2000.) One of the latest examples of this is a separate imprint from the Edition KID „PČESA“ Churches, village churches and churches at dairy farms by the author Ljubiša Rauški entitled "The destroyed catholic churches in anat" (2001). Published by the German Association "Donau" from Novi Sad shows 17 churches in total, whose appearance is witnessed partly in old photographs and partly sketches and paintings. Whether Serbian book titles dealing with a literature of recalling the German cultural heritage in the Western Balkans will succeed in the future to take over their own function, inter alia, remains to be seen particularly in the context of a culture of remembrance thereby promoting culture due to the process of coming to terms with the past.

\section{References:}

Adenauer, Georg (1962): Das Ehe- und Familienrecht im Mühlhäuser Reichsrechtsbuch. Bonn.

Curtius, Ernst Robert (1948). Europäische Literatur und lateinisches Mittelalter. Bern: A. Francke AG Verlag. Pp. 601, 506-521.

Deleuze, Gilles / Guattari, Félix (1976). Kafka. Für eine kleine Literatur. Frankfurt a. M.

Hackemann Matthias (Ed.) (2008). Jacobus de Voragine: Legenda AureaDie Heiligenlegenden des Mittelalters. Köln.

Dröge, Kurt (Ed.) (1995). Alltagskulturen zwischen Erinnerung und Geschichte. Beiträge zur Volkskunde der Deutschen im und aus dem östlichen Europa. (= Schriften des Bundesinstituts für ostdeutsche Kultur und Geschichte, 6). München, Oldenbourg.

Ehrismann, Gustav (1970). Die Grundlagen des ritterlichen Tugendsystems. In: Ritterliches Tugendsystem. Wege der Forschung / 56, Eifler, Günter [Ed.]. Darmstadt. 85-92.

Frenzel, Herbert A. and Elisabeth (1999). Daten deutscher Dichtung. 
Chronologischer Abriß der deutschen Literaturgeschichte. Bd 1. Von den Anfängen bis zum Jungen Deutschland. DTV: München.

Hartung, Hans Rudolf (1995), Soest und die Hanse. Jahn-Verlag: Soest. Hilkener (1932). Unsere Ziele. Volkswart, 1, Novi Sad.

Konstantinović, Zoran (1991). Der südeuropäische Modernismus und seine europäischen Verbindungen. In: Lauer, Reinhard (Ed.): Die Moderne in den Literaturen Südosteuropas, München.

Lehmann, Albrecht (1995). Erinnern und Vergleich. Flüchtlingsforschung im Kontext heutiger Migrationsbewegungen. Dröge Kurt (Ed.), Alltagskulturen zwischen Erinnerung und Geschichte. Beiträge zur Volkskunde der Deutschen im und aus dem östlichen Europa. (= Schriften des Bundesinstituts für ostdeutsche Kultur und Geschichte, 6). München, Oldenbourg. Pp 278. 15-30.

Liebhart, Wilhelm (1980). Die frühen Wittelsbacher als Städte- und Märktegründer in Bayern. In: Hubert Glaser (Ed.), Die Zeit der frühen Herzöge. Von Otto I. zu Ludwig dem Bayern (Wittelsbach und Bayern I/1), München. 307-318.

Liebhart, Wilhelm (2006). Zwischen Dorf und Stadt: der altbayerische Marktflecken im Spätmittelalter. In: Herbert Knittler (Hg.), Minderstädte, Kümmerformen, Gefreite Dörfer. Stufen zur Urbanität und das Märkteproblem (= Beiträge zur Geschichte der Städte Mitteleuropas XX), Linz. 279-304.

Lukić, Anton (1990). Dobro jutro, majstore! Prilozi građi za istoriju inđijskog zanatstva. Inđija: Grafičar Inđija.

Marković, Radoslav (1923). Indjija prilog za proučavanje naselja u Vojvodini. Novi Sad (1997): Matica srpska.

Mirambel, André (1966). Le développement des littératures du Sud-Est européen en relation avec les autres littérature de la fin du XVII siécle à nos jours. Sofia.

Mitrović, Andrej (1996). Srbi o Nemcima. Jedno viđenje drugog stvoreno istorijom. Belgrad: DBR Internacional Publishing. 7-23.

Николајевић, Константин (2003). Први векови српске историје : критички покушаји у периоду од првих пет (седам векова) српске историје / Константин Николајевић ; [превод са старословенског Ђорђевић, Матић]. - Београд : Пешић и синови : Стручна књига, (Београд : Стручна књига). 
Oberkersch Valentin(1978). India(=Ausgabe Indianer Heimatortausschuss) Stuttgart.

Panković, Dušan. Lirski memoari. Potraga za zaturelim osećanjima i zaboravljenim mislima. Novi Sad, Inđija: Matica spska, Narodna biblioteka „Dr. Đorđe Natošević“, 2000

Petrović, Ljubomir (1937). Fridrih I Barbarosa. Francusko-srpska knjižara a. M. Popovića. Beograd. 18-21.

Rauški, Ljubiša (2001). Srušene katoličke crkve u Banatu/ Die zerstörten katholischen Kirchen im Banat. In: KIRCHEN, Dorf- und Meierhofkirchen in der Vojvodina/ CRKVE, Seoske i salašarske crkve u Vojvodini. KID „PČESA“. Kikinda: Deutscher Verein „Donau“.

Ricœur, Paul (1996). Das Selbst als ein Anderer. München.

Schild, Wolfgang (1997). Die Geschichte der Gerichtsbarkeit. Hamburg: Verlag Georg D. W. Callwey.

Theiß A./ Wolf J. (2013), Lübeck. In: Martin Schubert (Ed.), Schreiborte des deutschen Mittelalters. Skriptorien, Werke. Mäzene. De Gruyter, Berlin/Boston: 284-288.

Timotijević Miroslav (2006). Rađanje moderne Privatnosti. Privatni život Srba u Habsburškoj monarhiji od kraja 17. do početka 19. veka. Beograd: Clio.

Wilhelm, Josep h (1961). Inđija. Donauschwäbische Beiträge. Heft 44. Freilassing: Pannonia Verlag.

Wodak, Ruth et.al. (1998): Zur diskursiven Konstruktion nationaler Identität. Frankfurt am Main: Suhrkamp (=Suhrkamp-Taschenbuch Wissenschaft; Bd. 1349).

Zeitler, Klaus (2001). Raumbezogene Identität - ein Entwicklungsfaktor für den ländlichen Raum? Eine soziologische Analyse der Determinanten und Inhalte ländlicher Raumentwicklung. Augsburg: (= Angewandte Sozialgeographie 42).

\begin{abstract}
Teaching German literature at Serbian universities is treated in the context of traditional philology. Additionally, it should be mentioned that the definition of the subject within German studies is a curriculum for the German language and literature studies abroad. But do studies of German literature in the sense of a literature written in a minor-
\end{abstract}


ity language cover the same specific field? This literature, originating in a language separated from its area of origin, certainly pursues several strands of development, particularly two, one determined by the majority language and the other in its own right, passed on by the language system of origin. Besides, historically speaking, the migratory movements of the community of the Danube Swabians show paradigmatically a coefficient of deterritorialization that influenced the language first of all. From this, Deleuze and Guattari defined a minority literature by means of a small or minor literature of a minority that uses a language spoken elsewhere by a large community. But, the spreading of the German language by scattering over different language communities in Eastern Europe and the isolation of each makes German minority literature appear unified. On the other hand, it seems, there is periodic direct exchange with the majority culture it is surrounded by. In the case of Serbian-German cultural contacts, studies on the urban and local history of Banat, by the German local historian and archaeologist Felix Millekers (b. 1858) came out, which were significant for Serbian history, as well as for the region where the research was carried out, and for the German definition of the area of origin. Obviously, the division into spheres of interest poses the question of the approach in order to define the subject. Do we speak of a minority literature viewed from the perspective of Serbian language and literature and, if this exists, does it include poetry written by members of the German minority community in the Serbian language? In other languages, there are such cases. Alternatively, do we speak of a minority literature viewed from the perspective of German studies?

German authors from southern Hungary and later from the Kingdom of the Serbs, Croats and Slovenians could never get close to the tendencies that were recognized in literature originating from the German language area. While the literature of the Danubian Swabians from southern Hungary and the Kingdom of the Serbs, Croats and Slovenians or of Yugoslavia does not even approach a literature awarded in the meantime with the Nobel Prize, their literature did contribute significantly to the self-discovery of the culture that characterizes the Danube Swabians. Although he was not a descendant of the Germans living in the area mostly populated by Serbs, Adam Müller-Gutenbrunn's Glocken der Heimat is a well-regarded novel that testifies to the destiny of the Germans living in Knićanin while Karl von Möller's Die Werschetzer Tat described the success of the Danube Swabians in cultivating land and spreading civilization.

Key words: bottom-up approach, coefficient of deterritorialization, cross-cultural communication, cultural practices, culture of remembrance, Danube Swabians, identity construction, market towns, minority literature, transcultural comparison

\section{Biographical statement}

MIODRAG VUKČEVIĆ, born 1971 in Hagen/ FR Germany, studied at the Universities in Belgrade, Novi Sad and at the Ruhr-Universität 
in Bochum, where he got a Masters degree in New German Literature in 1998. He started working first as a high school teacher for two years in Indjija and in 2001 he began as an assistant at the Faculty of Philology in Belgrade. His postgraduate degree in literary sciences he received in 2003 at the Faculty of Philology in Belgrade and in 2008 he got his doctoral degree in German literature. After being an assistant professor for German literature at the German department at Faculty of Philology in Belgrade for six years, now he is an associate professor at that department and a guest lecturer at the Faculty of Philology and Arts in Kragujevac. Since 2014 he is a member of the Babel Editorial Board. He is also a member of the national Organization for Realization Reproduction Rights in Serbia. His research areas mainly include the history of the German theater, medieval studies, the literature of the Early Modern Period, culture and literature of remembrance, Vergangenheitsbewältigung and the minority literature of the Danube Swabians.

E-mail: mvukcevic@fil.bg.ac.sr 